\title{
MENUMBUHKAN KREATIVITAS DAN KEMANDIRIAN GENERASI MUDA DI KELURAHAN PONDOK JAYA KOTA TANGERANG SELATAN
}

\author{
Imbron, Alvin Praditya, Arief Budiyanto, Laura Komala,Wahyu Andri Wibowo \\ Universitas Pamulang \\ Email: dosen02240@,unpam.ac.id
}

\begin{abstract}
Corona Virus or also called Covid 19 is a virus that can infect the respiratory system, Corona Virus or Covid 19 is easy to spread and spread very quickly, which originated from China to us to all countries in the world even in Indonesia was affected in just a matter of months. This makes Indonesia implement a policy to conduct lockdown and a large-scale social restriction policy to break the chain of this virus. The impact of this virus causes a weakening of economic turnover and the need for staples of basic commodities, this requires us to share in any form and to do anything to get rid of this corona virus, with that the presence of young people or young people is expected to grow creativity and independence for the younger generation is very meaningful and this is a form of sharing in goodness.
\end{abstract}

Keywords: Creativity, Independence

\begin{abstract}
Abstrak
Corona Virus atau di sebut juga Covid 19 adalah virus yang mampu menginveksi sistem pernapasan,Virus Corona atau Covid 19 ini mudah sekali menyebar dan sangat cepat penyebaranya,yang berawal dari cina hingga kita ke seluruh Negara di dunia bahkan di Indonesia pun terdampak hanya dalam hitungan bulan, hal ini membuat Indonesia menerapkan kebijakan untuk melakukan lockdown dan kebijakan pembatasan sosial berskala besar untuk memutus mata rantai virus ini,dampak dari virus ini menyebabkan perputaran ekonomi melemah dan kebutuhan bahan pokok melemah ,hal ini menuntut kita untuk saling berbagi dalam bentuk apapun dan mengerakan apapun untuk lepas dari virus corona ini ,dengan hal demikian kehadiran pemuda atau gerasi muda sangat di harapkan untuk itulah menumbuhkan krativitas dan kemandirian bagi generasi muda sangat berarti dan ini salah satu bentuk berbagi dalam kebaikan.
\end{abstract}

Kata Kunci: Kreativitas, Kemandirian 


\section{A. PENDAHULUAN}

Dalam kehidupan sosial peran pemuda amatlah berarti karna pemuda adalah garda terdepan dalam setiap permasalah sosial yang ada. Banyak upaya meningkatkan sumber daya manusia pada usia pemuda produktif salah satunya dengan melalui pendekatan pendidikan. Pendidikan nonformal salah satu jalur pendidikan yang berupaya dalam melakukan pemberdayaan terhadap pemuda produktif yakni melalui program pendidikan kecakapan hidup. Hal tersebut sejalan dengan terdapat Undang-undang No. 20 Tahun 2003 Pasal 26 Ayat (3) menyatakan: "Pendidikan non formal meliputi pendidikan kecakapan hidup, pendidikan anak usia dini, pendidikan kepemudaan, pendidikan pemberdayaan perempuan, pendidikan keaksaraan, pendidikan keterampilan dan pelatihan kerja, pendidikan kesetaraan, serta pendidikan lain yang ditujukan untuk mengembangkan kemampuan peserta didik". Adapun tujuan dari program ini adalah memberikan seseorang bekal pengetahuan, keterampilan dan kemampuan fungsional praktis serta perubahan sikap untuk bekerja dan berusaha kreatif dan mandiri, membuka lapangan kerja dan lapangan usaha serta memanfaatkan peluang yang dimilikinya sehingga dapat meningkatkan kualitas kesejahteraannya.

1. Target

Target dari kegiatan ini adalah kontribusi gerasi muda atau pemuda terhadap lingkungan sekitar di mana hal ini menumbuhkan kreativitas dan kemandirian gerasi muda dalam setiap menghadapi permasalahn lingkungan masyarakat sekitar.

2. Lokasi

Lokasi program Pengabdian Kepada Masyarakat terletak di Jl. Al Hidayah RT: 005/002 Kelurahan Pondok Betung Kecamatan Pondok Aren Kota Tangerang Selatan.

3. IPTEK (Komunikasi dan Teknologi Informasi)

Pada faktanya komunikasi merupakan salah satu kebutuhan manusia yang terjadi di mana saja. Komunikasi dapat terjadi setiap waktu oleh siapa saja. Komunikasi dari pemerintah kepada masyarakat merupakan salah satu cara pemerintah memberikan informasi agar masyarakat mengetahui hal-hal yang terjadi lingkup daerah yang dikelola oleh pemerintah. Komunikasi merupakan alat bagi individu dan kelompok dalam menyampaikan ide, pikiran atau perasaan dalam interaksi satu sama lain.

Tanpa komunikasi tak akan ada interaksi antara seseorang dengan orang lain, tak akan ada interaksi antar kelompok. Proses komunikasi ini tahap akhirnya ialah menciptakan persamaan persepsi antara yang menyampaikan pesan dengan yang menerima pesan. Melalui proses komunikasi seseorang dapat mencoba menciptakan makna bagi orang lain. Proses ini juga dapat menunjang seseorang membangun citra dirinya di hadapan orang lain yang menjadi sasaran komunikasi. Sehingga banyak tokoh yang menjadikan komunikasi sebagai alat pembentuk kredibilitas.

Dalam proses komunikasi tentunya komunikasi yang efektif adalah bentuk komunikasi yang seharusnya terjadi. Jika tidak efektif maka proses komunikasi tentu saja tidak sesuai dengan apa yang diharapkan. Proses komunikasi akan efektif jika informasi yang dikirimkan oleh pengirim pesan dapat diterima dengan sebenarnya sebagaimana yang dimaksudkan sehingga terjadi perubahan perilaku penerima pesan. Hal inilah yang menyebabkan konten pesan komunikasi menjadi sesuatu yang perlu diperhatikan dan dikemas dengan baik sehingga tidak menimbulkan bias bagi si penerima pesan. 
Proses komunikasi dipahami sebagai fasilitas yang memudahkan manusia dalam proses pemenuhan keperluan hidupnya dalam pergaulan yang sangat luas. Hal ini dapat dilihat bagaimana komunikasi dapat menciptakan keakraban, kecepatan, serta kenyamanan yang menunjang kehidupan menjadi lebih baik. Secara esensial, komunikasi mencakup pemindahan informasi dari seseorang kepada orang lain, lain dalam latar pergaulan dan kehidupan organisasi, maka sejatinya proses pemindahan informasi bahkan pengetahuan biasanya merupakan tujuan perilaku komunikasi antara individu dan individu dengan kelompok atau bahkan antar kelompok. Muaranya tercipta perubahan perilaku.

Pendapat lain menegaskan bahwa komunikasi akan menjadi efektif, bila memperhatikan lima prinsip yang disingkat dengan $\mathrm{REACH}$, yakni respect, empathy, audible, clarity, atau Care dan Humble, dalam konteks ini dipahami bahwa respect adalah saling menghargai, karena komunikasi tidak akan berjalan dengan baik jika tidak ada saling menghargai sedangkan empathy berarti kita harus berempati dengan lawan bicara.

4. Luaran Target

Target luaran dari kegiatan ini adalah menumbuhkan kreativitas dan kemandirian generasi muda untuk meningkatkan peran pemuda di lingkungan masyarakat dan bisa memanfaatkan teknologi informasi untuk memajukan perekonomian di lingkungan sendiri. Rincian luaran dalam program Pengabdian Kepada Masyarakat di jelaskan seperti berikut:

\begin{tabular}{|c|c|c|c|}
\hline No. & Jenis Luaran & Partisipasi Mitra & Target Luaran \\
\hline 1. & $\begin{array}{l}\text { Dilakukan } \\
\text { perencanaan kegiatan } \\
\text { Penyuluhan untuk } \\
\text { Menumbuhkan } \\
\text { kreativitas dan } \\
\text { kemadirian generasi } \\
\text { muda untuk peran } \\
\text { aktif di masyarakat }\end{array}$ & $\begin{array}{lr}\text { Mitra Diharapkan } \\
\text { mengajak warga lain } \\
\text { untuk r ikut } \\
\text { berpartisipasi dalam } \\
\text { pelaksanaan kegiatan }\end{array}$ & $\begin{array}{l}\text { Pemuda dan warga mampu } \\
\text { membangun serta } \\
\text { mengembangkan krativitas } \\
\text { serta kemandiran di } \\
\text { lingkungan sekitar. }\end{array}$ \\
\hline 2. & $\begin{array}{l}\text { Pelaksanaan } \\
\text { Penyuluhan } \\
\text { kreativitas strategi } \\
\text { bertahan, pemulihan } \\
\text { serta transisi dan } \\
\text { move on teknologi di } \\
\text { masa pandemic }\end{array}$ & $\begin{array}{l}\text { Mitra memfasilitasi } \\
\text { pelaksanaan kegiatan }\end{array}$ & $\begin{array}{l}\text { Adanya kerja sama pemuda } \\
\text { dan warga setempat untuk } \\
\text { saling membantu serta } \\
\text { mampu bertahan di masa } \\
\text { pandemic ini. }\end{array}$ \\
\hline 3. & $\begin{array}{l}\text { Monitoring dan } \\
\text { Evaluasi Kegiatan }\end{array}$ & $\begin{array}{l}\text { Mitra memfasilitasi } \\
\text { pelaksanaan kegiatan }\end{array}$ & $\begin{array}{l}\text { Pemuda /generasi muda } \\
\text { mampu } \\
\text { mengimplementasikan yang } \\
\text { telah di peroleh serta } \\
\text { melaporkan hasil kegiatan } \\
\text { setelah penyuluhan. }\end{array}$ \\
\hline
\end{tabular}




\section{B. METODE PELAKSANAAN KEGIATAN}

Metode kegiatan yang diberikan melalui bantuan dari satu tangan bisa meraih ke beberapa tangan dengan cara mengulurkan tangan melalui donasi kepada masyarakat yang membutuhkan di daerah Kelurahan Pondok Jaya RT 005/002 Tangerang Selatan. Setelah mendapatkan informasi dari hasil survey yang kami lakukan melalui wawancara melalui daring maka kami langsung membuat kelompok dalam membantu kesulitan para warga tersebut. Adapun tahapan-tahapan yang kami lakukan dalam Pengabdian Kepada Masyarakat ini diantaranya sebagai berikut:

1. Tahap Persiapan:

a. Survey Awal

Kami melakukan survey kepada lingkungan RT 005/002 Kelurahan Pondok Jaya Tangerang Selatan yang menggalang dana untuk para warga setempat yang membutuhkan. Setelah kami mendapatkan data warga setempat yang ada diperkampungan yang membutuhkan bantuan dikarenakan tidak mendapatkan penghasilan. Hal ini disebabkan karena tidak boleh melakukan kegiatan di luar rumah dan mereka tidak memiliki alat komunikasi yang memadai untuk melakukan pembelajaran daring.

b. Pemantapan dan penentuan lokasi dan sasaran.

Setelah survey dilakukan maka ditentukan lokasi pelaksanaan dan sasaran yang benar-benar membutuhkan bantuan. Adapun data yang kami dapatkan dari beberapa daerah di Kelurahan Pondok Jaya kami analisa dan kami distribusikan kepada orangorang yang benar-benar membutuhkan bantuan.

2. Tahap Pelaksanaan

Tahap ini kami memberikan donasi kepada Kelurahan Pondok Jaya untuk didistribusikan kepada warga sekitar yang terkena Dampak Covid-19 dan bantuan tersebut dibelikan sembako yang mereka butuhkan. Melalui media sosial, dana yang terkumpul kami berikan dan diserahkan melalui transfer ke ketua pelaksana dan langsung dibelikan sembako untuk segera didistribusikan kepada warga yang membutuhkan. Selain itu, Kami juga mengerakan pemuda dalam menggiatkan UKM dengan mengajak mereka bergabung dalam UMKM yang ada disekitar mereka. Sehingga ada pemasukan dan pengalaman yang baru dalam mendapatkan penghasilan yang halal dan thoyib.

3. Tahap Pelatihan

Untuk melaksanakan kegiatan tersebut digunakan beberapa metode pelatihan yaitu:

a. Metode ceramah

b. Metode tanya jawab

Maka dari itu, kegiatan ini membantu mereka untuk melakukan kegiatan kemitraan melalui pendistribusian sembako kepada para warga yang tidak mendapatkan penghasilan tersebut. Pemerintah menyarankan untuk melakukan kegiatan online sedangkan mereka alat komunikasinya masih terbilang belum memadai dan kuotanya tidak mencukupi. Selain itu, masyarakat yang juga masih di dalam perkampungan yang tidak memiliki alat komunikasi yang memadai juga. Sehingga tidak memungkinkan untuk penjualan online. Kami selaku Dosen Manajemen memiliki target dalam kegiatan ini untuk membantu kemitraan warga RT 005/002 untuk meningkatkan kegiatan UMKM di daerahnya secara online, sehingga mereka bisa mendapatkan penghasilan dan mencukupi kebutuhannya

Untuk menggerakkan mereka dan memudahkan mereka melakukan aktivitasnya kami memberikan bantuan dalam bentuk sumbangan sembako. Pendistribusian sembako 
dibantu oleh bapak Ketua RT 005/002 langsung ke rumah para warga yang membutuhkan bantuan tersebut. Hal ini memudahkan kami dalam melakukan pengabdian kepada masyarakat langsung ke sasaran yang membutuhkan.

\section{HASIL DAN PEMBAHASAN}

\section{Tahap Persiapan}

a. Survey Awal

Kami melakukan survey kepada lingkungan RT 005/002 Kelurahan Pondok Jaya Tangerang Selatan yang menggalang dana untuk para warga setempat yang membutuhkan. Setelah kami mendapatkan data warga setempat yang ada diperkampungan yang membutuhkan bantuan dikarenakan tidak mendapatkan penghasilan. Hal ini disebabkan karena tidak boleh melakukan kegiatan di luar rumah dan mereka tidak memiliki alat komunikasi yang memadai untuk melakukan pembelajaran daring.

b. Pemantapan dan penentuan lokasi dan sasaran.

Setelah survey dilakukan maka ditentukan lokasi pelaksanaan dan sasaran yang benar-benar membutuhkan bantuan. Adapun data yang kami dapatkan dari beberapa daerah di Kelurahan Pondok Jaya kami analisa dan kami distribusikan kepada orang-orang yang benar-benar membutuhkan bantuan.

\section{Tahap Pelaksanaan Pengabdian Kepada Masyarakat}

Tahap ini kami memberikan donasi kepada Kelurahan Pondok Jaya untuk didistribusikan kepada warga sekitar yang terkena Dampak Covid-19 dan bantuan tersebut dibelikan sembako yang mereka butuhkan. Melalui media sosial, dana yang terkumpul kami berikan dan diserahkan melalui transfer ke ketua pelaksana dan langsung dibelikan sembako untuk segera didistribusikan kepada warga yang membutuhkan. Selain itu, Kami juga membantu dalam menggiatkan UKM dengan mengajak mereka bergabung dalam UMKM yang ada disekitar mereka. Sehingga ada pemasukan dan pengalaman yang baru dalam mendapatkan penghasilan yang halal dan thoyib.

\section{KESIMPULAN DAN SARAN}

\section{Simpulan}

Pelaksanaan Pengabdian kepada masyarakat di laksanakan di Jl. Al-Hidayah RT: 005/002 kelurahan Pondok Jaya Kecamatan Pondok Aren Kota Tangerang Selatan. Pelaksanaan kegiatan ini mengajak warga 005/002 untuk mengimplementasikan berderma dan bertahan di masa pandemic dengan cara saling membantu pemuda antar warga dan lingkungan supaya tumbuh rasa kepedulian pemuda terhadap tetangga dan bisa bersosialisasi untuk mendapat informasi supayaa tidak ada kesalah pahaman komunikasi antar warga yang dapat menimbulkan perpecahan dan saling tuduh Ketika ada warga yang sakit hati dan mencurigai bahwasannya terkena Covid-19.

Dalam laporan akhir kegiatan ini mungkin banyak kekurangan, untuk itu kami berharap masukan serta kritikan dalam rangka perbaikan untuk kegiatan-kegiatan Pengabdian Kepada Masyarakat selanjutnya. Semoga dalam kegiatan Pengabdian Kepada Masyarakat ini dapat bermanfaat bagi masyarakat sekitar dan lingkungan Universitas Pamulang serta pihak lainnya yang termotivasi untuk terjun ke lapangan dalam rangka membantu lingkungan sekitar. 
Kami mengucapkan terima kasih kepada seluruh pihak yang telah mendukung kegiatan ini demi tercapainya kelancaran Pengabdian Kepada Masyarakat laksanakan dan kami team Dosen memohon maaf apabila dalam laporan kegiatan ini masih banyak kekurangan.

\section{Saran}

Berawal dari hal kecil bisa memunculkan sesuatu yang besar, karena berderma (Berbagi) sangat dianjurkan dalam agama dan saling tolong menolong merupakan hal bermanfaat. Semoga bisa menjadi ladang amal dan pahala yang berlimpah bagi siapa saja yang mau berderma dan tolong menolong dalam hal kebaikan.

\section{Ucapan Terima Kasih}

Rasa Terimakasih kami haturkan kepada segenap pihak yang telah ikut membantu lancarnya kegiatan Pengabdian Kepada Masyarakat dengan judul "Menumbuhkan Kreativitas Dan Kemadirian Generasi Muda di Kelurahan Pondok Jaya Kota Tangerang Selatan" kepada:

1. Rektor Dr. H. Dayat Hidayat, M.M, Rektor Universitas Pamulang Tangerang Selatan Banten.

2. Dr. Ali Maddinsyah, S.E., M.M., selaku Ketua LPPM Universitas Pamulang Tangerang Selatan - Banten.

3. Dr. Kasmad, S.E., M.,M., selaku Ketua Program Studi Manajemen Universitas Pamulang Tangerang Selatan - Banten.

4. Dr. Udin Ahidin, S.E., M.M., C.M.A, Selaku Wakil Program Studi Manajemen Universitas Pamulang Tangerang Selatan - Banten.

5. Drs. Waluyo Jati, M.M., Selaku Sekretaris Program Studi Manajemen Universitas Pamulang Tangerang Selatan - Banten.

6. Fery Ismail, selaku Ketua RT 005/002 Kelurahan Pondok Jaya, Kota Tangerang Selatan Banten.

\section{DAFTAR PUSTAKA}

Agoes, Sukrisno. (2012). Auditing Petunjuk Praktis Pemeriksaan Akuntan Oleh Akuntan Publik, Jilid 1, Edisi Keempat. Jakarta: Salemba Empat.

Azra, Azyumardi. (2003). Berderma untuk Semua. Jakarta: Tiraju.

BBC Travel dengan judul The law of generosity combatting coronavirus in Pakistan.

Elga, A. Yusrianto. (2007) Menjadi Kaya dengan Sedekah, Yogyakarta: Mitra Pustaka.

Green, M. J., \& Phillips, M. L. (2004). Social threat perception and the evolution of paranoia. Neuroscience \& Biobehavioral Reviews, 28(3), 333-342. doi:10.1016/j.neubiorev.2004.03.006

Haqqi, Musthafa Syaikh Ibrahim. (2010). Sedekah Berbalas Kontan: Balasan Berlipat Terhindar Musibah, Solo: Aqwam Media Profetika.

Kurniawan. P. (2020), "Pengaruh Kecerdasan Intelektual Dan Kecerdasan Emosional Terhadap Kinerja Karyawan Pada PT. Bank Rakyat Indonesia (Persero) Cabang Tangerang Merdeka”. Jenius, Vol. 3. No. 3. 
Kurniawan, P. (2019), "Pengaruh Disiplin Kerja, Motivasi, Dan Komitmen Organisasi Terhadap Kinerja Karyawan Pada PT. Bank Rakyat Indonesia (Persero) Cabang Tangerang Merdeka", Jurnal Ekonomi Efektif, Vol. 1. No. 2.

Kurniawan, P. (2019), Pengaruh Motivasi dan Disiplin Kerja Terhadap Produktifitas Kerja Karyawan Pada PT. Daya Perkasa. Jurnal Mandiri. Vol. 2. No.2.

Moore, KennethD, (2005). Effective Instructional Strategies, From Theory to Practice, London: Sage Publications.

Pasal 4 ayat (1) Undang-Undang Dasar Negara Republik Indonesia Tahun 1945.

Peraturan Pemerintah Republik Indonesia Nomor 21 tahun 2020 Tentang Pembatasan Sosial Berskala Besar Dalam Rangka Percepatan Penanganan Corona Virus Disease 2019 (Covid-19).

Raihani, N. J., \& Bell, V. (2019). An evolutionary perspective on paranoia. Nature human behaviour, 3(2), 114-121.

Solihin, D. (2020), Pengaruh Kepercayaan Pelanggan dan Promosi Terhadap Keputusan Pembelian Konsumen Pada Online Shop Mikaylaku Dengan Minat Beli Sebagai Variabel Intervening. JURNAL MANDIRI: Ilmu Pengetahuan, Seni, dan Teknologi, Vol. 4, No. 1.

Solihin, D. (2020), Faktor-Faktor yang Mempengaruhi Kinerja Pemasaran Pada PT. Prima Ufuk Semesta Studi Pada Outlet Rekanan PT. Prima Ufuk Semesta di Wilayah JABODETABEK, Jurnal Semarak, Vol. 3 No.1.

Solihin, D. (2020), Pengaruh Kualitas Pelayanan, Harga, Dan Promosi Terhadap Keputusan Pelanggan Dalam Memilih Klub Basket Satria Indonesia Tangerang Selatan, Jurnal Pemasaran Kompetitif, Vol. 3, No. 3.

Solihin, D. (2019), Pengaruh Current Ratio dan Debt to Equtity Ratio Terhadap Return on Asset (ROA) Pada PT. Kalbe Farma Tbk. Jurnal Kreatif, Vol. 7. No. 1.

UU No. 6 Tahun 2018 tentang Karantina Kesehatan (Lembaran Negara Republik Indonesia Tahun 2018 Nomor 128, Tambahan Lembaran Negara Republik Indonesia Nomor 6236). 